\title{
A Causal Model of the Mutual Relationships Between Academic Bullying, Suicidal Thinking, and Psychological Immunity Among University Students
}

\author{
Amani Abdel-Tawab Saleh Hassan ${ }^{a}$ \\ ${ }^{a}$ Assistant Professor at Department of Mental Health, Prince Sattam Bin Abdulaziz University, Saudi Arabia and Al-Azhar \\ University, A.salh@psau.edu.sa
}

Article History: Received: 10 November 2020; Revised 12 January 2021 Accepted: 27 January 2021; Published online: 5 April 2021

\begin{abstract}
The research aims to identify the causal model that explains the relationship between academic bullying, psychological immunity, and suicidal thinking among university students. Besides, it recognizes gender differences in research variables. The sample has consisted of (134) male and (139) female students from Prince Sattam bin Abdul-Aziz University and King Faisal University for the academic year 2020-2021. The researcher prepared the academic bullying scale and the suicidal thinking scale, and the psychological immunity scale was taken from the study of Al-Takhaina. The study has shown a statistically significant correlation between academic bullying and suicidal thinking. There are statistically significant differences between males and females in academic bullying and suicidal thinking favoring females. The results have also shown statistically significant differences between males and females in psychological immunity favoring males. The research recommends launching counseling and training programs for both bullies and bullying victims to gain insight into their behaviors and rectify them.
\end{abstract}

Keywords: LGS, mathematics, teacher, difficulty

\section{Introduction}

Universities are considered scientific and intellectual institutions worldwide. Their administrators tend to provide democratic climates and reactive relationships between staff members \& administration and between administration \& students based on dialogue and persuasion rather than power and obligation. Universities are considered one of the most important institutions where tools for development and progress are made by providing students with the opportunity to pursue knowledge and develop it. It deepens their values of freedom, dialogue, and tolerance that qualify them to deal effectively with others in different life areas. When university staff and students feel justice, patience, and academic freedom, they develop their thoughts and unleash their creativity. Speaking about university life, we have found that the faculty member is the primary core as he/she motivates students and provides them with excitement \& joy, enthusiasm, tolerance, familiarity, and respect. It is found that there are faculty members in some universities who practice a kind of behavior that is away from teaching manners. They deliberately use authority and powers to reflect a personal viewpoint that is imposed on students. Thus, students' responses vary due to their teachers' behaviors (Shehata, 2000).

The bullying behavior practiced by some teachers is one of the factors that affect students' performance. Suppose the student finds him/herself in an educational environment full of fear of assault, threat, and inferiority. This situation may lead to behavioral disturbances and negative attitudes towards him/herself and others (Mayhew, 2015). It is found that there are cases of committing suicide among adolescents due to exposure to bullying, in addition to symptoms of depression and impulsivity that those victims suffer (Staurt, 2011). Mental immunity plays a vital role in overcoming challenges \& difficulties and dealing with different threatening situations. It works to enforce the individual's thinking and help him/her deal with various problems and pressures (Al-Jazaar, 2018). Lack of psychological immunity makes the individual lose self-control and overestimate the standards of judging things. Consequently, the level of emotional maturity declines, allowing irrational thoughts to dominate the individual's thinking, which is often destructive (Abu Riah, 2006). Students' psychological immunity makes them face the adverse effects resulting from psychological pressures, whether social or academic (AlShawi, 2018)

Hepburn (2000) has conducted a study on teachers' bullying over students, in which one teacher has admitted that he has practiced intimidation and violent methods against students. Besides, Twemlow et al. (2006) have reported that $45 \%$ of teachers have acknowledged that they have practiced violence and bullying against their students. Similarly, James et al. (2008) have revealed that $30 \%$ of students were subjected to harassment by teachers. After analyzing the data indicating the high ratio of bullying, it is cleared that there is a lack of statistics 
about bullying by adults in schools and universities in the Arab context. The phenomenon of bullying in universities is a serious educational and social problem. It negatively affects educational activities \& events and leads to low performance. It tightens up its ability to achieve cognitive, emotional, and social development for students and prepare good citizens who can think positively, effectively, and productively. Besides, effective learning can only occur in a supportive atmosphere where there is an adequate level of psychological \& financial security and protection from violence, danger, and threat (Hindi, 2013).

Bullying leads to many problems, including low academic achievement, suicide attempts, and violent \& deadly acts at all education levels (Chibbaro, 2013). Several studies have examined the relevance between bullying and suicide or having suicidal thoughts (Marisa, 2012; Williams, 2017; Hollis, 2019; Duan, 2020). Mental immunity is one of the most important methods of preventing psychological and social problems. According to Kamel (2002), everyone has a psychological immune system. If he/she loses it, he/she will be exposed to acquire negative characteristics known as symptoms of psychological immunodeficiency, including lack of happiness and pleasure in life. However, strengthening the individual's mental immunity helps reduce post-traumatic stress (Al-Sharif, 2016). Hence, university students need to maintain high psychological immunity because it raises their moral and intellectual state. It works on reconstructing their cognitive knowledge and modifying their behavior. Moreover, it shapes their way of dealing with life and work situations. It makes them away from thinking wrongly or illogically and never feels of committing suicide as a suitable solution to get rid of their problems.

The significance of the research is highlighted in dealing with bullying in universities, as most of the previous efforts have focused on examining the phenomenon of bullying in schools only. The study aims to reveal the causal model that explains the interrelationships between academic bullying and its dimensions (verbal bullying, teaching bullying, and reactive bullying). It deals with psychological immunity as an intermediate variable. It explains suicidal thinking and its dimensions (the protective developmental aspect, the subjective psychological aspect, the social aspect, and the emotional \& intellectual aspect) among university students. It highlights their differences according to male/female genders.

\section{Theoretical Framework}

Academic Bullying: Bullying is a problem that has been deeply rooted in human minds since ancient times. Recently, it has been widely spread globally (Al-Khafaji, 2014). There have been different views on the concept of bullying. Rigby (2010) has stated that bullying is a systematic and organized harm that one person does against another for no reason. Tabet et al. (2019) have defined it as an intentional and repeated harmful action or a set of actions by another person or others, with an imbalance of power between the bully and the victim. It includes physical bullying and relational bullying (verbal and social exclusion). It was believed that bullying was related in one way or another to illiteracy or lack of education. This understanding soon dissipated when they knew that bullying existed in both modern or developing countries in an equal manner due to the connection of this behavior with the human psyche rather than its relation to tablets and digital devices (Al-Araj, 2019). Marraccini et al. (2018) have indicated that teachers may use their authority to punish or belittle students, going over the university disciplinary regulations' limits. Olweus (1993) states that bullying has occurred when students are repeatedly exposed to hostile actions. Twemlow (2005) has mentioned that the bullying teacher is the person who uses authority and capacity to punish or belittle students beyond regulations. Lieberman et al. (2011) have pointed out that all kinds of bullying and abuse are essential factors that lead to depression and suicidal thinking.

Olweus (2010) has stated that bullying is a general problem that has serious long-term effects on adolescents, including suicidal behavior. Therefore, Marraccini et al. (2018) have pointed out the importance of developing policies at the university level to overcome all kinds of bullying by paying particular attention to teacher bullying over students. Bullying is a common problem in colleges, which is reported more common among male students than female students (Chapell, 2004). Besides, it is revealed that high rates of bullying are by lecturers (Marisa, 2012). The results of Al-Zeyoudi's (2016) study, which was conducted on a sample of (400) male and female students, have indicated that the degree of academic bullying as viewed by female students was moderate. However, female students suffer more than males from the practices of academic bullying. It was also found that there is a correlation between academic bullying practices and students' negative attitudes towards the university. Litwiller et al. (2013) have concluded that bullying in all its kinds impacts individuals' mental health and psychological well-being, especially adolescents. The results of the Williams et al. (2017), which was conducted on a sample of (233) ninth-grade students, have shown that females practice bullying behaviors (verbal/social and cyberbullying) more than males do.

Moreover, the results of John et al. (2018) have shown that victims of bullying are more at risk of self-harm and suicidal behaviors than others. Extremera et al. (2018) have also linked emotional intelligence with suicidal thinking on a sample of (1660) teenagers exposed to cyberbullying. The study results have shown that teenagers 
with high levels of emotional intelligence have a lower level of suicidal thinking and a high level of self-esteem. Similarly, Hollis (2019) has found a positive correlation between exposure to bullying and individual health \&psychological disorders among faculty members exposed to bullying. Such health and psychological disorders were insomnia, need for counseling, increased alcohol addiction, and suicidal thinking.

Psychological Immunity: The immune system can learn. There are many ways of communication between the central and immune systems that make chemical messages. These are operated strongly in these two systems, which are the same that abundantly show up in the nerve regions that regulate emotion. Consequently, a new field appears known as Psychoneuroimmunology. It studies the relationships, interactions, and mutual influences between behavior, body immunity, and the nervous system (Goleman, 2004). Kamel (1999) defines psychological immunity as "a mental system of systematic ideas capable of producing counter-ideas to ideas destructive to the individual or society, through which the individual acquires an objective intellectual approach that he uses in generating ideas; against social diseases and destructive ideas." Bona (2014) indicates that psychological immunity is an integrated preventive system that works to strengthen and enhance the self to help the individual interact efficiently with stressful circumstances. Al-Takhaina (2018) states that mental immunity represents an integrated and multidimensional unit of adaptive capabilities that act as shields to prevent psychological crises. Al-Ahmad (2020) adds that mental immunity is an emotional system that the individual uses to give him the ability to perceive psychological risks, protect them and enhance life. Ali (2019) believes that psychological immunity is an integrated system that helps the individual cope with emotional conflicts and pressures, protect oneself from emotional harm, adapt to various environmental variables, and justify or rationalize destructive emotions and convert them into acceptable emotions. It is believed that individuals with a high level of psychological immunity have extraordinary esteem and stature. They can set themselves positive goals \& expectations, solve problems, and make the right decisions (Goldsen, 2011). The psychological immune system is represented as a filter for the emotional messages carried by events, relationships, activities, and everyday situations (Kagan, 2006). Individuals who were bullied during childhood and adolescence suffer from various mental disorder forms in adulthood (Ikeda, 2020). Psychological immunity is vital in facing crises, pressures, and negative feelings. It plays an essential role in logical thinking, impulse control and management, flexible thinking, and optimism to achieve life goals and objectives (Votikane, 2004; Stack, 2014). There is a positive correlation between psychological immunity, forgiveness, self-awareness, self-control, flexible thinking, feeling happy, and embracing life (Al-Aqili, 2017; Al-Ahmad, 2020).

Suicidal Thinking:Thinking about suicide is considered a psychological problem, as it shows a defect in the level of compatibility of the individual. It also reveals a personality weakness that cannot efficiently deal with difficult issues and psychological traumas. It is also considered a biological problem due to the changes and alterations in the individual's organic structure (Hamimi, 2012). Rudd (2009) defines suicidal thinking as the thought process associated with the suicide process. Al-Daidan (2015) defines it as a process that includes some perceptions that could end in severe harm or lead to death. The person who thinks about suicide suffers from building or maintaining a mutual personal relationship (Al-Khalidi, 2008). Exposure to others' abuse is another reason for the individual to become frustrated due to being in a bad situation, especially when repeated (Campbell, 2017). It is crucial when examining suicide or the thoughts that come before it to focus on studying the factors that limit committing suicide (Safyia, 2016). Tabet et al. (2019) have indicated that bullying or abuse harms an individual's identity and develops the symptoms of depression, social isolation, and environmental pressures. It is found that despair, depression, trauma, violence, exposure to abuse in all its forms, life stress, aggressive behavior, and low levels of self-esteem are related to suicidal thinking (Al-Mashaan 2010; Aoe, 2016; John, 2018; Hollis, 2019; Duan, 2020).

\section{Procedures}

The research sample consists of all Saudi university students enrolled in their colleges for the academic year 2020/2021. The descriptive design was used for its appropriateness to achieve the aim of the research. The research tool was subjected to a pilot study sample consisting of (70) male/female students from Prince Sattam bin Abdulaziz University and King Faisal University to calculate the psychometric properties.

The researcher has prepared an academic bullying scale consisting of (28) statements. It wasaimed to measure academic bullying among university students. It was distributed on three dimensions (verbal bullying, teaching bullying, and reactive bullying). There is a five-Likert scale in front of each statement. The positive items are rated as: $5=$ strongly agree, $4=$ agree, $3=$ neutral, $2=$ disagree, and $1=$ strongly disagree. The negative items and their numbers $(13,20,22,24,28)$ are rated in reverse. For the preparation of this scale, some previous studies and related literature have been reviewed. The scale was subjected to a group of (9) specialists in psychology and mental health in its initial form. They have judged the extent the scale achieves its goal, the correctness, clarity of its statements, the extent of statements' fitness to the dimension, and the possibility of adding, deleting or amending some statements. Consequently, (2) statements were deleted, and the linguistic wording of some statements was modified. The jury members' agreement was between (77.7-100), which has indicated the validity 
of the scale. The factorial validity of the scale was calculated by determining the factor structure. The results of the factor analysis of the pilot sample were determined by the method of principal components and the orthogonal rotation by Alpharimax method. It has shown four factors that were interpreted considering the loading of statements equal to or greater than (0.35) (Amin, 2008). Table (1) illustrates the loading of scale statements with these factors. The reliability of the scale was calculated using Cronbach's alpha coefficient. This value was $(0.80)$ for the verbal bullying dimension, $(0.78)$ for the teaching bullying dimension, $(0.77)$ for the reactive bullying dimension, and (0.79) for the scale as a whole. Thus, these values indicate a high-reliability coefficient for the scale. The internal consistency was calculated by calculating the degree of each of the statements and the dimension. The consistency ratios were ranged between (0.395-0.690), see Table (2). It is clear from the table that the correlation coefficients between the degree of each of the statements and the dimension are statistically significant at (0.01) level.

The scale aimed to measure suicidal thinking among university students was also prepared by the researcher after reviewing the literature (Al-Dhaidan, 2015). It also consisted of (20) statements and answered according to a Five-Likert scale. It was also presented to a group of (9) specialists in psychology and mental health in its initial form. The jury members' agreement was between (88.8-100), which has indicated the validity of the scale. The Pearson Correlation Coefficient value was (0.84), which is statistically significant at (0.01) level, which indicates the validity of the scale used in the current research. The scale's reliability was calculated using Cronbach's alpha coefficient. This value was equal to (0.86), which indicates a high-reliability coefficient of the scale.

Al-Takhaina (2018) has prepared the scale used for psychological immunity. The scale consists of (53) statements, (41) positive statements, and (12) negative statements. It is distributed in four dimensions (the preventive-developmental dimension, the psychological self-dimension, the psychological dimension, and the emotional-intellectual dimension). The statements are answered according to a five-Likert-scale. The scale was administered to a sample of university students in Jordan by the author, where the validity of the scale was calculated by interrater validity. The internal consistency was calculated by extracting the correlation coefficients between the scale statements and their dimensions. According to Cronbach's alpha, all of them were significant at the level of (0.05), and the scale reliability coefficients were ranged between (0.79-0.80). These were ranged between $(0.80-0.91)$ by test-re-test method, which confirms the scale's reliability. The Pearson Correlation Coefficient value was (0.82), which is statistically significant at (0.01). It indicates the validity of the scale used in the current research. The scale's reliability was calculated using the Cronbach's alpha coefficient, and this value was equal to (0.83), and this value indicates a high-reliability coefficient of the scale.

\section{Findings and Discussion}

First Hypothesis:There is a positive and statistically significant relationship between the dimensions of academic bullying (verbal bullying, teaching bullying, and reactive bullying) and the overall score and suicidal thinking among university students. The results are summarized in Table (1).

Table (1): The correlation coefficients between students' scores on the academic bullying scale with its dimensions and their scores on the suicidal thinking scale.

\begin{tabular}{|c|c|c|c|c|c|}
\hline Scale & Values & $\begin{array}{l}\text { Verbal } \\
\text { bullying }\end{array}$ & $\begin{array}{l}\text { Teaching } \\
\text { bullying }\end{array}$ & $\begin{array}{l}\text { Reactive } \\
\text { bullying }\end{array}$ & $\begin{array}{c}\text { Academic } \\
\text { bullying scale } \\
\text { as overall }\end{array}$ \\
\hline \multirow{2}{*}{$\begin{array}{c}\text { Suicidal } \\
\text { thinking scale }\end{array}$} & $\begin{array}{r}\text { Pearson } \\
\text { correlation } \\
\text { coefficient }\end{array}$ & $* * 0.444$ & $* * 0.474$ & $* * 0.448$ & $* * 0.488$ \\
\hline & $\begin{array}{l}\text { Significanc } \\
\text { e level }\end{array}$ & 0.01 & 0.01 & 0.01 & 0.01 \\
\hline
\end{tabular}

Table (1) shows a positive correlation between students' scores on the academic bullying scale with its dimensions, the scale overall, and their scores on the suicidal thinking scale. All Pearson correlation coefficients are statistically significant at a level of (0.01). It is due to the student's exposure to continuous bullying from a faculty member. Accordingly, feelings of frustration and threats are aroused among them. Besides, their sense of powerlessness to defend themselves negatively affects their psychological compatibility. Therefore, the personality is disturbed, disintegrated, and hit by some psychological diseases that lead them to think about suicide. This result is consistent with some other studies (Stuart, 2011; John, 2018; Hollis, 2019; Duan, 2020). 
Second Hypothesis:There is a statistically significant negative relationship between the dimensions of academic bullying (verbal bullying, teaching bullying, and reactive bullying), psychological immunity (the preventive-developmental dimension, the subjective psychological dimension, the social dimension, and the emotional-intellectual dimension), and the overall score among university students. The results are shown in Table (2).

Table (2): The correlation coefficients values between students' scores on the academic bullying scale and its dimensions and their scores in the psychological immunity scale and its dimensions.

\begin{tabular}{|c|c|c|c|c|c|}
\hline $\begin{array}{l}\text { Psychological } \\
\text { immunity scale }\end{array}$ & Values & $\begin{array}{l}\text { Verbal } \\
\text { bullying }\end{array}$ & $\begin{array}{l}\text { Teaching } \\
\text { bullying }\end{array}$ & $\begin{array}{l}\text { Reactive } \\
\text { bullying }\end{array}$ & \begin{tabular}{l}
\multicolumn{1}{c}{ Overall } \\
academic \\
bullying scale
\end{tabular} \\
\hline \multirow[t]{2}{*}{$\begin{array}{r}\text { Preventive- } \\
\text { developmental }\end{array}$} & $\begin{array}{l}\text { Pearson } \\
\text { correlation } \\
\text { coefficient }\end{array}$ & $0.040-$ & $0.038-$ & *0.141 - & $0.075-$ \\
\hline & Significance level & 0.507 & 0.530 & 0.020 & 0.215 \\
\hline \multirow[t]{2}{*}{$\begin{array}{l}\text { Subjective- } \\
\text { psychological }\end{array}$} & $\begin{array}{l}\text { Pearson } \\
\text { correlation } \\
\text { coefficient }\end{array}$ & $* * 0.191-$ & $* * 0.165-$ & $* * 0.255-$ & $* * 0.216-$ \\
\hline & Significance level & 0.002 & 0.006 & 0.01 & 0.01 \\
\hline \multirow[t]{2}{*}{$\begin{array}{l}\text { Emotional- } \\
\text { intellectual }\end{array}$} & $\begin{array}{l}\text { Pearson } \\
\text { correlation } \\
\text { coefficient }\end{array}$ & $0.022-$ & $0.047-$ & *0.121 - & $0.065-$ \\
\hline & Significance level & 0.716 & 0.442 & 0.046 & 0.285 \\
\hline \multirow[t]{2}{*}{ Social dimension } & $\begin{array}{l}\text { Pearson } \\
\text { correlation } \\
\text { coefficient }\end{array}$ & $* * 0.264-$ & $* * 0.205-$ & $* * 0.181-$ & $* * 0.234-$ \\
\hline & Significance level & 0.01 & 0.01 & 0.003 & 0.01 \\
\hline \multirow[t]{2}{*}{ Overall } & $\begin{array}{l}\text { Pearson } \\
\text { correlation } \\
\text { coefficient }\end{array}$ & $* * 0.158-$ & *0.139 - & $* * 0.221-$ & **0.183 - \\
\hline & Significance level & 0.009 & 0.021 & 0.01 & 0.002 \\
\hline
\end{tabular}

Significant at $0.05 *$

\section{Significant at $0.01 * *$}

Third Hypothesis:There is a statistically significant relationship between the scores of the suicidal thinking scale and the dimensions of the psychological immunity scale (the preventive-developmental dimension, the subjective-psychological dimension, the social dimension, the emotional-intellectual dimension) and the overall score among university students. The results are mentioned in Table (3).

Table (3): The values of correlation coefficients between the students' scores in the suicidal thinking scale and the psychological immunity scale.

\begin{tabular}{|l|l|l|l|l|l|l|}
\hline Scale & Values & $\begin{array}{l}\text { Preventive } \\
\text { development } \\
\text { al }\end{array}$ & $\begin{array}{l}\text { Psychological } \\
\text { subjective }\end{array}$ & $\begin{array}{l}\text { Social } \\
\text { aspect }\end{array}$ & $\begin{array}{l}\text { Emotional- } \\
\text { intellectual }\end{array}$ & $\begin{array}{l}\text { Overall } \\
\text { psychological } \\
\text { immunity scale }\end{array}$ \\
\hline $\begin{array}{l}\text { Suicidal } \\
\text { thinking } \\
\text { scale }\end{array}$ & $\begin{array}{l}\text { Pearson } \\
\text { correlation } \\
\text { coefficient }\end{array}$ & $* * 0.259-$ & $* * 0.417-$ & $* * 0.194-$ & $* * 0.481-$ & $* * 0.419-$ \\
\cline { 2 - 7 } & Significance level & 0.01 & 0.01 & 0.01 & 0.01 & 0.01 \\
\hline
\end{tabular}


It is clear from Table (3) that there is a negative correlation between students' scores on the suicidal thinking scale, the dimensions of the psychological immunity scale, and the overall ranking. All Pearson correlation coefficients were statistically significant at the level of (0.01). It shows that when the individual becomes unable to control feelings and loses the ability to survive and strengthen oneself, he/she finds a difficult to deal efficiently with the pressures of life. As a result, the individual develops thoughts related to death and thoughts of suicide. This result agrees with (Al-Mashaan, 2010; Aoe, 2016; Williams, 2017; Hollis, 2019; Duan, 2020)

Fourth Hypothesis:There are no statistically significant differences between male and female university students' mean scores in the academic bullying scale, dimensions, and overall ranking. Results are shown in Table (4).

Table (4): $t$-value results of the mean scores of male and female students in the academic bullying scale

\begin{tabular}{|c|c|c|c|c|c|c|c|}
\hline Scale & Gender & $\mathbf{N}$ & Mean & Std. Deviation & df & t-value & Sig. level \\
\hline \multirow{2}{*}{ Verbal } & Male & 134 & 21.49 & 8.76 & \multirow{8}{*}{271} & \multirow{2}{*}{ *1.96 } & \multirow{2}{*}{0.05} \\
\hline & Female & 139 & 23.37 & 6.98 & & & \\
\hline \multirow{2}{*}{ Teaching } & Male & 134 & 24.22 & 8.56 & & \multirow{2}{*}{$* 2.02$} & \multirow{2}{*}{0.04} \\
\hline & Female & 139 & 26.12 & 6.84 & & & \\
\hline \multirow{2}{*}{ Reactive } & Male & 134 & 25.63 & 7.59 & & \multirow{2}{*}{$* * 3.10$} & \multirow{2}{*}{0.002} \\
\hline & Female & 139 & 28.17 & 5.86 & & & \\
\hline \multirow{2}{*}{ Overall } & Male & 134 & 71.35 & 23.45 & & \multirow{2}{*}{$* * 2.49$} & \multirow{2}{*}{0.013} \\
\hline & Female & 139 & 77.65 & 18.09 & & & \\
\hline
\end{tabular}

$0.05 *$ significant at $0.01 * * \quad$ significant at

Table (4) shows statistically significant differences between the mean scores of male and female students in the dimensions of the academic bullying scale and the overall scale in favor of females. This result is consistent with Al-Zeyoudi's (2016) study, while it does not concur with Chapell et al. (2004), who have shown that bullying is more common among males.

Fifth Hypothesis:There are no statistically significant differences between male and female university students' mean scores on the psychological immunity scale. Results are summarized in Table (5).

Table (5): T-test results for males' and females' mean scores in the psychological immunity scale.

\begin{tabular}{|c|c|c|c|c|c|c|c|}
\hline Scale & Gender & $\mathbf{N}$ & Means & $\begin{array}{l}\text { Std. } \\
\text { Deviation }\end{array}$ & Df & T-value & Sig. level \\
\hline \multirow{2}{*}{$\begin{array}{l}\text { Preventive } \\
\text { developmental }\end{array}$} & Male & 134 & 59.52 & 7.48 & \multirow{10}{*}{271} & \multirow{2}{*}{$* * 3.21$} & \multirow[b]{2}{*}{0.01} \\
\hline & Female & 139 & 56.66 & 7.25 & & & \\
\hline \multirow{2}{*}{$\begin{array}{l}\text { Psychological } \\
\text { subjective }\end{array}$} & Male & 134 & 52.24 & 7.37 & & \multirow{2}{*}{ **3.90 } & \multirow{2}{*}{0.01} \\
\hline & Female & 139 & 48.58 & 8.09 & & & \\
\hline \multirow{2}{*}{ Social } & Male & 134 & 45.41 & 6.49 & & \multirow{2}{*}{$* * 2.13$} & \multirow{2}{*}{0.01} \\
\hline & Female & 139 & 43.71 & 6.74 & & & \\
\hline \multirow{2}{*}{$\begin{array}{l}\text { Emotional } \\
\text { intellectual }\end{array}$} & Male & 134 & 36.01 & 6.32 & & \multirow{2}{*}{$* * 2.79$} & \multirow{2}{*}{0.01} \\
\hline & Female & 139 & 34.01 & 5.54 & & & \\
\hline \multirow{2}{*}{$\begin{array}{l}\text { Overall } \\
\text { psychological } \\
\text { immunity scale }\end{array}$} & Male & 134 & 193.19 & 20.83 & & \multirow[b]{2}{*}{$* * 3.84$} & \multirow[b]{2}{*}{0.01} \\
\hline & Female & 139 & 182.95 & 23.08 & & & \\
\hline
\end{tabular}

Table (5) shows statistically significant differences between the mean scores of males and females in the dimensions of the psychometric immunity scale and the overall scale in favor of males. It may be due to the sufficient support that the males receive by family or society through socialization methods and the determination and toughness that characterizes males in facing the course of life. Hence, this may lead to strengthen their psychological immunity more than females.

Sixth Hypothesis:There are no statistically significant differences between male and female university students' mean scores on the scale of suicidal thinking. Results are shown in Table (6). 
Table (6): T-test results of males' and females' mean scores on the suicidal thinking scale.

\begin{tabular}{|c|c|c|c|c|c|c|c|}
\hline Scale & Gender & $\mathbf{N}$ & Mean & $\begin{array}{c}\text { Std. } \\
\text { Deviation }\end{array}$ & Df & $\begin{array}{r}\text { T- } \\
\text { value }\end{array}$ & $\begin{array}{l}\text { Sig. } \\
\text { level }\end{array}$ \\
\hline \multirow{2}{*}{$\begin{array}{c}\text { Suicidal } \\
\text { thinking scale }\end{array}$} & Male & 134 & 46.50 & 17.72 & \multirow{2}{*}{271} & \multirow{2}{*}{$\begin{array}{r}* 5.08 \\
* \quad\end{array}$} & \multirow{2}{*}{0.01} \\
\hline & Female & 139 & 57.94 & 19.39 & & & \\
\hline
\end{tabular}

Table (6) shows statistically significant differences between males' mean scores on the suicidal thinking scale in favor of females. It is due to the emotional and social repression that dominates girls in Saudi society. It generates negative feelings of loneliness and leads to thinking about suicide. This finding is not in agreement with Williams et al. (2017), which have shown that bullying is more common among males than females.

Seventh Hypothesis: A causal model can link academic bullying dimensions (verbal bullying, teaching bullying, and reactive bullying) and the psychological immunity dimensions (the preventive-developmental dimension, the subjective-psychological dimension, the social dimension, and the emotional-intellectual dimension) as an intermediate variable and suicidal thinking. The casual model (Figure1) links between academic bullying dimensions, psychological immunity dimensions as an intermediate variable, and suicidal thinking was tested to test this hypothesis.

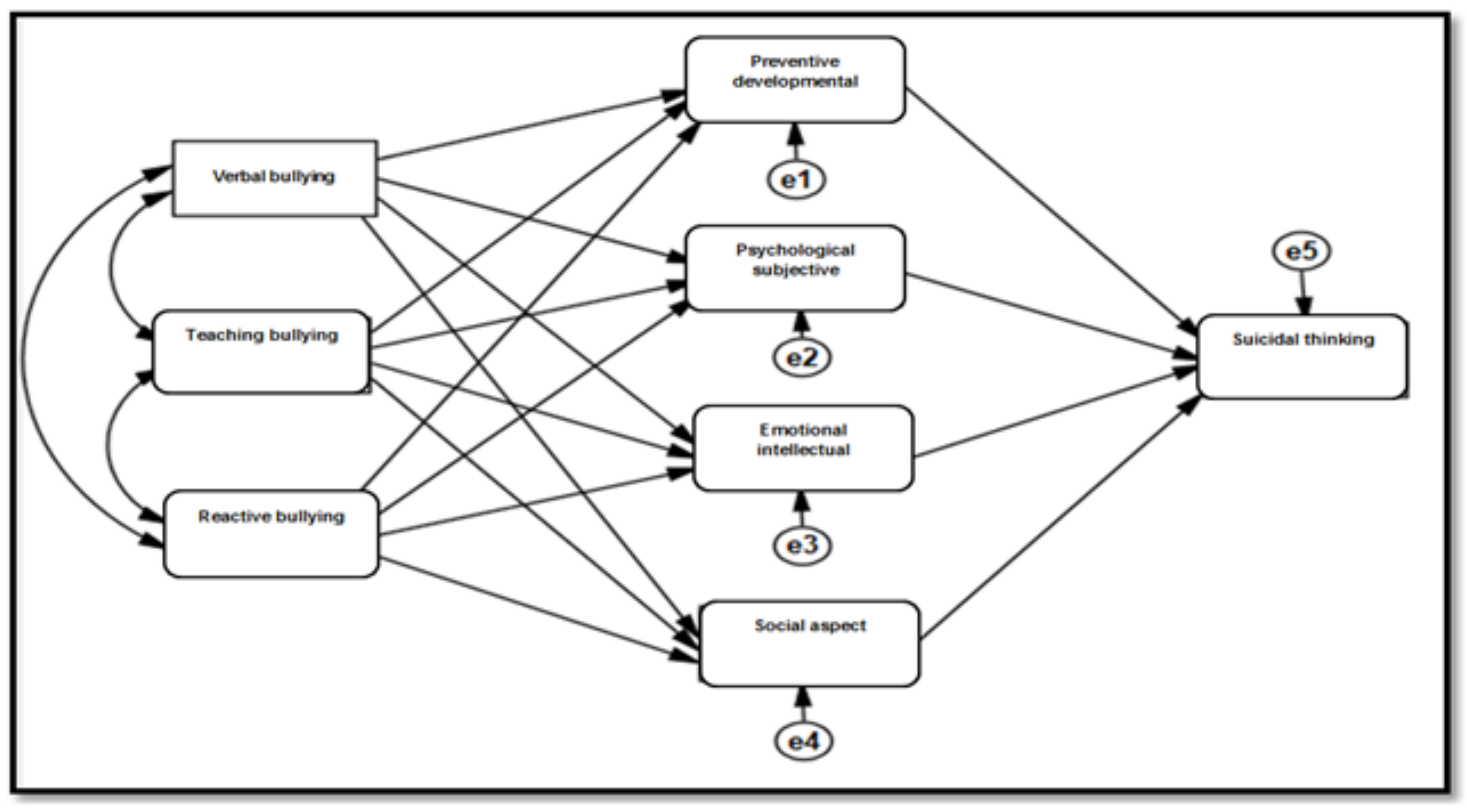

Figure (1): The suggested model's schematic diagram for analyzing the scheme between the research variables.

IBM SPSS Amos v.20 was used to test the causal model's appropriateness to the study sample's data, as shown in Table (7).

Table (7): Values of Goodness of fit indices of the suggested casual model.

\begin{tabular}{|l|c|c|}
\hline The Goodness of fit indices & Values & Acceptable limits \\
\cline { 1 - 2 } Chi-square & 26.64 & \multirow{2}{*}{ Chi-square/df $>3$} \\
\cline { 1 - 2 } Degrees of freedom & 9 & \\
\cline { 1 - 2 } Chi-square/D & 2.96 & NFI $\geq 0.95$ \\
\hline Normed Fit Index (NFI) & 0.953 & CFI $\geq .90$ \\
\hline Comparative Fit Index (CFI) & 0.952 & \\
\hline
\end{tabular}




\begin{tabular}{|c|c|c|}
\hline Incremental Fit Index (IFI) & 0.957 & IFI $\geq 0.90$ \\
\hline goodness of fit index (GFI) & 0.964 & GFI $\geq 0.95$ \\
\hline $\begin{array}{c}\text { Standardized Root Mean Square Residual } \\
\text { (SRMR) }\end{array}$ & 0.047 & SRMR <0.08 \\
\hline $\begin{array}{c}\text { Root Mean Square EPL-VAT or of } \\
\text { Approximation (RMSEA) }\end{array}$ & 0.043 & RMSEA $<0.08$ \\
\hline
\end{tabular}

(Hooper, 2008)

It is clear from the above Table (7) that the Goodness of fit indices' values were all within the acceptable limits. Thus, it indicates the fitness of the causal model with the data derived from the study sample. Table (8) shows the standard and non-standard values of the direct effects between the causal model variables.

Table (8): The direct effects between the variables of the causal model.

\begin{tabular}{|c|c|c|c|c|c|c|c|}
\hline $\begin{array}{l}\text { Independent } \\
\text { variables }\end{array}$ & $\begin{array}{l}\text { Dependent } \\
\text { variables }\end{array}$ & Value & $\begin{array}{l}\text { Standard } \\
\text { error }\end{array}$ & $\begin{array}{l}\text { Standard } \\
\text { value }\end{array}$ & Z-value & Sig. le & \\
\hline $\begin{array}{l}\text { Preventive } \\
\text { developmental }\end{array}$ & \multirow[t]{4}{*}{ Suicidal thinking } & $0.716-$ & 0.138 & $0.263-$ & $5.179-$ & 0.000 & Sig. at 0.01 \\
\hline $\begin{array}{l}\text { Psychological } \\
\text { subjective }\end{array}$ & & $0.763-$ & 0.142 & $0.306-$ & 5.391- & 0.000 & Sig. at 0.01 \\
\hline Social aspect & & $0.066-$ & 0.182 & $0.022-$ & $0.360-$ & 0.719 & Not sig. \\
\hline $\begin{array}{l}\text { Emotional- } \\
\text { intellectual }\end{array}$ & & $1.153-$ & 0.180 & $0.350-$ & $6.417-$ & 0.000 & Sig. at 0.01 \\
\hline Verbal bullying & \multirow{3}{*}{$\begin{array}{l}\text { Preventive } \\
\text { developmental }\end{array}$} & 0.080 & 0.095 & 0.087 & 0.842 & 0.400 & Not sig \\
\hline $\begin{array}{l}\text { Teaching } \\
\text { bullying }\end{array}$ & & 0.194 & 0.109 & 0.207 & 1.773 & 0.076 & Not sig. \\
\hline $\begin{array}{l}\text { Reactive } \\
\text { bullying }\end{array}$ & & $0.306-$ & 0.114 & $0.289-$ & $2.685-$ & 0.007 & Sig. at 0.01 \\
\hline Verbal bullying & \multirow{3}{*}{$\begin{array}{l}\text { Psychological } \\
\text { subjective }\end{array}$} & $0.046-$ & 0.110 & $0.046-$ & $0.422-$ & 0.673 & Not sig. \\
\hline $\begin{array}{l}\text { Teaching } \\
\text { bullying }\end{array}$ & & 0.133 & 0.120 & 0.130 & 1.110 & 0.267 & Not sig. \\
\hline $\begin{array}{l}\text { Reactive } \\
\text { bullying }\end{array}$ & & $0.373-$ & 0.123 & $0.322-$ & $3.042-$ & 0.002 & Sig. at 0.01 \\
\hline Verbal bullying & \multirow{3}{*}{$\begin{array}{l}\text { Emotional- } \\
\text { intellectual }\end{array}$} & 0.146 & 0.098 & 0.174 & 1.483 & 0.138 & Not sig. \\
\hline $\begin{array}{l}\text { Teaching } \\
\text { bullying }\end{array}$ & & 0.030 & 0.102 & 0.035 & 0.294 & 0.768 & Not sig. \\
\hline $\begin{array}{l}\text { Reactive } \\
\text { bullying }\end{array}$ & & $0.277-$ & 0.103 & $0.285-$ & $2.699-$ & 0.007 & Sig. at 0.01 \\
\hline Verbal bullying & \multirow[t]{3}{*}{ Social aspect } & $0.253-$ & 0.090 & $0.334-$ & $2.808-$ & 0.005 & Sig. at 0.01 \\
\hline $\begin{array}{l}\text { Teaching } \\
\text { bullying }\end{array}$ & & 0.019 & 0.102 & 0.025 & 0.190 & 0.849 & Not sig. \\
\hline $\begin{array}{l}\text { Reactive } \\
\text { bullying }\end{array}$ & & 0.055 & 0.100 & 0.062 & 0.546 & 0.585 & Not sig. \\
\hline
\end{tabular}

Figure (2) shows the suggested model's schematic diagram for analyzing the diagram between the research variables after modification. 


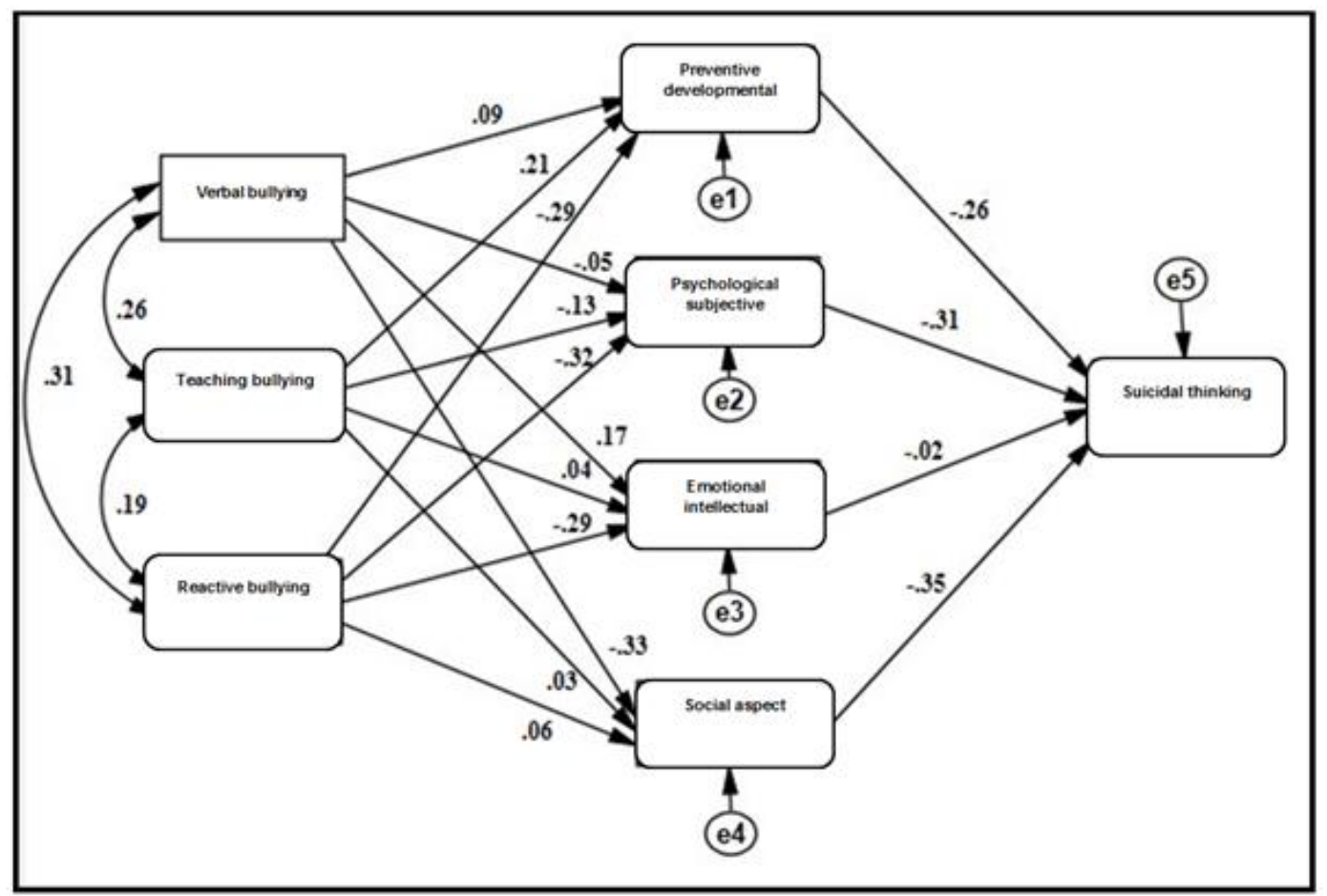

Figure (2): The suggested model's schematic diagram for analyzing the diagram between the research variables after modification.

Table (9) shows the standard values of the academic bullying variable's indirect effects over the suicidal thinking variable through the psychological immunity variable.

Table (9): Standard values of the academic bullying variable.

\begin{tabular}{|c|c|c|c|c|c|c|c|}
\hline $\begin{array}{l}\text { Independent } \\
\text { variable }\end{array}$ & $\begin{array}{l}\text { Intermediate } \\
\text { variables }\end{array}$ & $\begin{array}{l}\text { Dependent } \\
\text { variable }\end{array}$ & Value & S.E. & $\mathbf{Z}$ & \multicolumn{2}{|c|}{ Sig. level } \\
\hline \multirow[t]{4}{*}{ Verbal bullying } & $\begin{array}{l}\text { Preventive } \\
\text { developmental }\end{array}$ & \multirow{4}{*}{$\begin{array}{l}\text { Suicidal } \\
\text { thinking }\end{array}$} & $0.023-$ & 0.027 & $0.839-$ & 0.401 & Not sig. \\
\hline & $\begin{array}{l}\text { Psychological } \\
\text { subjective }\end{array}$ & & 0.014 & 0.034 & 0.419 & 0.675 & Not sig. \\
\hline & $\begin{array}{l}\text { Emotional } \\
\text { intellectual }\end{array}$ & & $0.004-$ & 0.011 & $0.357-$ & 0.721 & Not sig. \\
\hline & Social aspect & & 0.117 & 0.046 & 2.521 & 0.012 & Sig. at 0.05 \\
\hline \multirow[t]{4}{*}{ Teaching bullying } & $\begin{array}{l}\text { Preventive } \\
\text { developmental }\end{array}$ & \multirow{4}{*}{$\begin{array}{l}\text { Suicidal } \\
\text { thinking }\end{array}$} & $0.054-$ & 0.032 & $1.700-$ & 0.089 & Not sig. \\
\hline & $\begin{array}{l}\text { Psychological } \\
\text { subjective }\end{array}$ & & $0.040-$ & 0.035 & $1.133-$ & 0.257 & Not sig. \\
\hline & $\begin{array}{l}\text { Emotional } \\
\text { intellectual }\end{array}$ & & $0.001-$ & 0.003 & $0.222-$ & 0.825 & Not sig. \\
\hline & Social aspect & & $0.009-$ & 0.046 & $0.191-$ & 0.849 & Not sig. \\
\hline \multirow[t]{4}{*}{ Reactive bullying } & $\begin{array}{l}\text { Preventive } \\
\text { developmental }\end{array}$ & \multirow{4}{*}{$\begin{array}{l}\text { Suicidal } \\
\text { thinking }\end{array}$} & 0.076 & 0.031 & 2.486 & 0.013 & Sig. at 0.05 \\
\hline & $\begin{array}{l}\text { Psychological } \\
\text { subjective }\end{array}$ & & 0.099 & 0.035 & 2.832 & 0.005 & Sig. at 0.01 \\
\hline & $\begin{array}{l}\text { Emotional } \\
\text { intellectual }\end{array}$ & & 0.006 & 0.018 & 0.354 & 0.723 & Not sig. \\
\hline & Social aspect & & $0.022-$ & 0.041 & $0.535-$ & 0.593 & Not sig. \\
\hline \multicolumn{8}{|c|}{ The overall indirect effect } \\
\hline Verbal bullying & \multirow{3}{*}{$\begin{array}{l}\text { Psychological } \\
\text { immunity }\end{array}$} & \multirow{3}{*}{$\begin{array}{l}\text { Suicidal } \\
\text { thinking }\end{array}$} & 0.150 & 0.067 & 2.247 & 0.025 & Sig. at 0.05 \\
\hline Teaching bullying & & & 0.005 & 0.067 & 0.075 & 0.940 & Not sig. \\
\hline Reactive bullying & & & 0.007 & 0.063 & 0.113 & 0.910 & Not sig \\
\hline
\end{tabular}




\section{Conclusions and Recommendations}

It is concluded that there exists a positive correlation between students' scores on the academic bullying scale with its dimensions, the scale overall, and their scores on the suicidal thinking scale. It is due to the student's exposure to continuous bullying from a faculty member. A negative correlation exists between students' scores on the suicidal thinking scale, the psychological immunity scale's dimensions, and the overall ranking. Significant differences between the mean scores of male and female students are found in the dimensions of the academic bullying scale and the overall scale, which favors the females. At the same time, significant differences between males' and females' mean scores in the psychometric immunity scale dimensions and the overall scale favor the males. However, statistically significant differences between males' mean scores on the suicidal thinking scale favor the females.

It is strongly recommended to launch counseling and training programs for both bullies and victims of bullying. There is a need to gain insight into their behaviors, modify it, and correct their misconceptions using cognitive and behavioral models. It is emphasized to benefiting from the results of this research and considering them as an indicator to expand the scope of examining bullying at higher education institutions.

\section{Acknowledgments}

Scientific Research Deanship has funded this project at Prince Sattam Bin Abdulaziz University through Proposal No. (2020/02/17035).

\section{References}

Shehata, Hassan; Abu Amira, Mohabbat. (2000). Teachers and Learners: Their Patterns, Behaviors, and Roles, Cairo: Arab House Bookshop, pp. 44.

Mayhew, M.; Grunwald, H.; Dey, E. (2015). Curriculum matter: Creating a positive climate for diversity from the students' perspective, Research in Higher Education, 46(4), 389-412, pp. 389.

Staurt, Cassel; V., Bell; A., Springer; J., Fred, B. (2011). Analysis of stat bulling laws and policies office of planning, Evaluation and policy development, US department of education time- British, Journal of Clinical Psychology 29, 361-371.

Al-Jazar, Rania Khamis; Al-Balashouni, Shaima Ahmed; Suleiman, Sanaa Muhammad. (2018). Psychological Immunity of university students and Its relation to Moral Intelligence and Academic Performance, Journal of Scientific Research in the Arts, 19 (7), 130-164, pp. 128.

Abu Riah, Muhammad Massad. (2006). Behavioral problems among the pupils of high and low ability to be misled. Master Thesis, Faculty of Education, Fayoum University, pp. 23.

Al-Shawi, Suleiman Ibrahim. (2018). Psychological immunity and perceived self-efficacy among students of the College of Social Sciences at Imam Muhammad bin Saud Islamic University, Journal of the College of Education, Tanta University, 69 (1), 428-464, pp. 431.

Hepburn, A. (2000). Power lines: Derrida, discursive psychology and the management of accusations of teacher bullying. British Journal of Social Psychology, 39, 605-628.

Twemlow, S., Fonagy, P., Sacco, F., \& Brethour, J. (2006). Teachers who bullying students: A hidden trauma. International Journal of Social Psychiatry, 52(3), 187-198.

James, D.; Lawlor, M.; Courtney, P.; Flynn, A.; Henry, B.; Murphy, N. (2008). Bullying behavior in secondary schools: What roles do teachers play? Child Abuse Review, 16, 160-173.

Hindi, Saleh. (2013). The reality of the school climate in basic schools in Jordan from the viewpoint of Islamic education teachers and tenth grade students and its relationship to some variables. The Jordanian Journal of Educational Sciences, 7 (2), 105-123, pp. 105.

Chibbaro, S. (2013). School counselors and the cyber bully: Interventions and implications. Professional School counseling, 11(1), pp. 65-67.

Marisa E.; Lisa L.; Joseph S. (2012). College Students' Perceptions of Professor/Instructor Bullying: Questionnaire Development and Psychometric Properties. Journal of American College Heath, 63, (8), 563572.

Williams, S.; Langhinrichsen-Rohling, J.; Wornell, C.; Finnegan, H. (2017). Adolescents Transitioning to high school: Sex differences in bullying victimization associated with depressive symptoms suicide ideation, and suicide attempts, The Journal of School Nursing, 33(6) 467-479.

Hollis, L. (2019). Analysis of faculty wellness and workplace bullying. Paper presented at the Annual Meeting of the American Educational Research Association (AERA). Toronto, Ontario, Canada, Apr 6, 15.

Duan, S., Duan, Z., Li, R., Wilson, A., Wang, Y., Jia, Q., Yang, Y., Xia, M., Wang, G. Jin, T., Wang, S., \& Chen, R. (2020). Bullying victimization, bullying witnessing, bullying perpetration and suicide risk among adolescents: A serial mediation analysis, Journal of affective disorders, 273 (April 26), 274-279. 
Kamel, Abd Al-Wahhab Muhammad. (2002). Contemporary Trends in Psychology. Cairo: The Anglo-Egyptian Library, pp. 320.

Al-Sharif, Rola Ramadan. (2016). The effectiveness of a counseling program to support the mental immune system and reduce some traumatic disorders among adolescents of families affected by the recent aggression on Gaza (2014), Master Thesis, Islamic University of Gaza.

Al-Khafaji, Adham Rajab (2014). The impact of a counseling program on developing social skills among victims of school bullying. Master Thesis, College of Basic Education, Al-Mustansiriya University, pp. 2.

Rigby, K. (2010). Bulling intervention in school: Six basic approaches. Canberwell: Acer press.

Tabet, C.; Abou Samah, J.; Hakim, N.; Karam, E. (2019). What Do We Know About Bullying: A Review of Reviews from 2014- 2019. The Arab Journal of Psychiatry. 30 (2), 115 - 128, pp. 123.

Al-Araj, Abdullah. (2019). Academic bullying. Published article, Makkah Journal, retrieved on December 22, 2019, pp. 66, https://makkahnewspaper.com/article/1500206.

Marraccini, M.; Brick, L.; Weyandt, L. (2018). Instructor and peer bullying in college students: Distinct typologies based on Latent Class Analysis. Journal of American College Health, 66 (8), 799-808.

Olweus, D. (1993). Bullying at school: What we know and what we can do. Cambridge, MA: Blackwell, pp. 9.

Twemlow, S.; Fonagy, P. (2005). The prevalence of teachers who bully students in schools with differing levels of behavioral problems. The American Journal of Psychiatry, 162 (12), pp. 2378-2389.

Lieberman, R.; Cowan, K. (2011). Bullying and youth suicide: Breaking the connection, C. Principal Leadership; Reston, 12, (2), 12-17.

Olweus, D. (2010). Understanding and researching bullying: Some critical issues, pp. 9.

Chapell, M; Casey, D; De la Cruz, C; Ferrell, J; Forman, J; Lipkin, R; Newsham, M; Sterling, M; \& Whittaker, S. (2004). Bullying in college by students and teachers. Adolescence, pp. 39 (153).

Al-Zeyoudi, Majid Mohammed. (2016). The Degree of Academic Bullying by Faculty Members at Taibah University and Its Relation to Students' Attitudes Toward the University, Journal of Studies for Educational Sciences, 43 (3), 1813-1827

Litwiller, B.; Brausch, A. (2013). Cyber bullying and physical bullying in adolescent suicide: The role of violent behavior and substance use, Journal of Youth Adolescence, 42, 675-684.

John, A.; Glendenning, AC.; Marchant, A.; Montgomery, P.; Stewart, A.; Wood, S.; Hawton, K. (2018). Selfharm, suicidal behaviors, and cyber bullying in children and young people: Systematic review. Journal of medical internet research; 20 (4)1-29.

Extremera, N.; Quintana-Orts, C.; Mérida-López, S.; Rey, L. (2018). Cyber bullying victimization, self-esteem and suicidal ideation in adolescence: Does emotional intelligence play a buffering role? Frontiers in psychology; 9-367.

Goleman, Daniel. (2004). The Intelligence of Emotions, translated by Hisham Al-Hinnawi, Cairo: General Book Authority, pp. 327.

Kamel, Abd al-Wahhab Muhammad. (1999). Principles of Psychology between Theory and Practice, Cairo: The Egyptian Renaissance Library, pp. 46.

Bona, K. (2014). An exploration of the psychological immune system in Hungarian gymnasts, M.A, university of jyvaskela, pp. 33.

Al-Takhaina, Qusay Khaled. (2018). The Role of Psychological immunity in Predicting Psychological Empowerment of Mu'ta University Students in Light of Some Demographic Variables, Master Thesis, Deanship of Postgraduate Studies, Mu'tah University, pp. 1.

Al-Ahmad, Muhammad Rafeeq. (2020). Psychological immunity and its relationship to happiness among a sample of orphan students in the upper primary stage in Jerash governorate. Journal of Educational and Psychological Sciences, 4 (9), 125-144.

Ali, Amani Adel. (2019). Psychological immunity and its relationship to factors of perceived family resilience among mothers of children with a mental disability who are able to learn, The Egyptian Journal of Psychological Studies, 29 (104), 51-104.

Goldsen, Brooks. (2011). Resilience in children, translated by Safaa Al-Aasar. Cairo: The National Center for Translation, pp. 44.

Kagan, H. (2006). The psychological immunity system, A new look at protection and survival- Herman, library of Congress, U. S. A, pp. 66.

Ikeda, T.; Hori, D.; Ikeda, Y.; Takahashi, T.; Shiraki, N; Andrea, C; Ohtaki, Y.; Doki, S.; Oi, Y.; Sasahara, S.; Saito, T.; Matsuzaki, I. (2020). School IJime (Bullying) Experience Is a possible risk factor for current psychological distress among science city workers: A cross-sectional study in Tsukuba, Japan, Bullying Experience and Current Depression, (250), 223-231.

Votikane, S. (2004). Goal directedness in relation to life satisfaction, psychological immune system and depression in first-semester university students in Lative Baltic, journal of psychology, 5(2), 19-30.

Stack, C.; Parrila, P.; Torppa, M. (2014). Using a multidimensional measure of resilience to explain life satisfaction and academic achievement of adults with reading difficulties, Journal of Learning disabilities, 48(6), 646-657. 
Al-Aqili, Jabbar Wadi. (2017). Psychological immunity among university students and its relationship to selfawareness and forgiveness, Arab studies in education and psychology, Arab Educators Association (81), 423454.

Hamimi, Attab. (2012). Realizing severe anxiety and its relationship to depression and feelings of hopelessness among a group of people who attempted suicide. Knowledge Journal, 12, 189-199.

Rudd, M. (2009). The suicidal ideation scale: A self- report measure of suicidal ideation. Manuscript submitted for publication, pp. 33 .

Al-Dhaidan, Al-Hamidi Muhammad. (2015). Coping styles and their relationship to suicidal thinking among university students, Journal of the College of Education, Al-Azhar University, 162 (4), 539-572.

Al-Khalidi, Atallah. (2008). Contemporary Guiding Issues, Amman: Safaa Publishing House, pp. 45.

Campbell, S.; Kessler, R.; Ursano, R.; Rosellini, A.; Afifi, T.; Colpe, L.; Heeringa, S.; Nock, M.; Sampson, N.; Sareen, J.; Schoenbaum, M.; Sun, X.; Jain, S.; Stein, M. (2017). Associations of childhood bullying victimization with lifetime suicidal behaviors among new U.S. Army soldiers. Depress Anxiety, 34, 701-710.

Safia, Sharple Yacoub. (2016). Personal and demographic variables that predict suicidal thinking in a sample of adolescents. Master Thesis, Al-Ahliyya Amman University, pp. 5.

Al-Mashaan, Awaid. (2010). Exposure of children to physical and psychological abuse by parents. Second Regional Conference on Psychology, November 29-December 1, Egyptian Psychologists Link, 585-608.

Aoe, T.; Shetty, sh.; Sivilli, T.; Blanton, C.; Ellis, H.; Geltman, P.; Cochran, J.; Taylor, E.; Lankau, E.; Cardozo, B. (2016). Suicidal ideation and mental health of bhutanese refugees in the United States. Journal of Immigrant Minority Health, 18, 828-835.

Amin, Osama Rabih. (2008). Statistical analysis of multiple variables using spss, Cairo, Anglo library, pp. 196.

Hooper, D.; Coughlan, J.; Mullen, M. (2008). Equation modelling: Guidelines for determining model fit. Electronic Journal of Business Research Methods, 6(1), 53-60. 